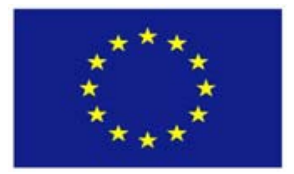

x demhow vr3.jpg

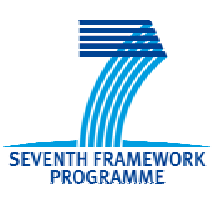

Project funded under the

Socio-economic Sciences and Humanities

\title{
HOUSING AND DEMOGRAPHIC CHANGE
}

\author{
John Doling \\ College of Social Sciences \\ University of Birmingham \\ Birmingham UK \\ j.f.doling@bham.ac.uk
}

Paper given to the ENHR workshop on Home Ownership and Globalisation

Building on Home Ownership: Housing policies and Housing Strategies

13-14 November 2008

OTB Research Institute for Housing, Planning and Mobility Studies

Delft University of Technology, The Netherlands

This paper is based, in part, on work carried out for the DEMHOW project which is funded by the European Commission under its Framework 7 Programme (contract number SSH7CT-2008-216865). I am grateful to the support of my research partners on the project. particularly my colleague Nick Horsewood. 


\section{INTRODUCTION}

Following significant rates of growth in the western member states over the entire post war period, and in many of the eastern member states over the period after the breakup of the Soviet Union, home ownership is now the predominant tenure in Europe; with some twothirds of households now owning, Europe may be accurately described as a "union of home owners" (Doling and Ford 2007). Recent discussion about this growth and other developments in the housing systems of advanced economies have been markedly skewed toward the impact of globalisation and the associated rise of neo-liberalism (eg Doling and Ford 2003; Malpass 2006; Ronald 2008; Stephens 2003). One element of much of this discussion has been that these macro processes have underlain - in some interpretations, forced - the tendency for states to retreat from social forms of housing provision in favour of private forms, especially home ownership. Thus Peter Malpass has argued that while responding in different ways each country is doing so in "response to the pressures arising from globalisation ... [resulting in] .... a general tendency to cut back on universal services funded from taxation... Housing ... has been at the leading edge of reform” (Malpass 2006:109).

Whatever the strength of such explanation, there is another macro process that has broadly progressed in parallel with the developments in home ownership: whilst, following the baby boom in the decade or so immediately following the end of the second world war fertility rates have had some cyclical variation, the general trend has been downward, and this has been allied to a steady increase in life expectancy (European Commission 2005). Fewer babies and longer lives have resulted in higher median ages in all member states, to the greying of Europe. This ageing of the populations of advanced economies has put their governments under pressure, arguably every bit as significant as globalisation, to restructure their welfare systems. In reviewing the literature on population ageing and welfare provision, Castles indicates that "the logic of the(ir) argument is transparent" (Castles 2003: 4). On the one hand pensions and cash benefits to older people combined with health and social care constitute the two largest programmes in most of the larger economies, accounting to about two-thirds of total social spending. On the other hand, the proportion of older people in those same economies is growing, so that there will be increasing upward pressure on the costs of these elements of social spending. Moreover, because older people form a large potential voting block, it will be difficult for elected governments to resist their demands. In these circumstances, and given the twin pressures of globalisation and the fiscal implications that arise from a fall in dependency ratios, government spending on those welfare areas not directed at older people may be most vulnerable to cuts. In such a scenario, spending on social housing provision for young people and families might not have the highest priority and whether through positive action to promote it or simply the withering away of other opportunities, home ownership may have come to occupy a larger share of national housing systems.

On this view, therefore, what can sometimes appear a rather mechanistic interpretation of globalisation as an independent variable that brings about an irresistible retrenchment of the social element in housing provision can be extended to an equally mechanistic interpretation that the same housing outcomes are the inevitable consequence of the ageing of populations. The position taken in this paper is that while on the available evidence the ageing of populations in Europe appears to have had, and seems likely to continue to have, significant impacts on housing outcomes, the impacts are not necessarily, or only, in that direction nor necessarily immutable. Indeed, the linkages between population and housing may actually be 
much more complex, including the possibility that the independent-dependent relationship is reversed.

It is elements of this complexity that the paper explores. Following presentation of the scale and extent of ageing populations, the paper uses the Life Cycle Model (LCM) as a vehicle for exploring the linkages between demographic structures and home ownership. While the intention in this has been to focus on European experience, in practice the available evidential base is patchy and unsystematic so that studies from other advanced economies, especially the US, are also drawn upon. Even so, the evidence allows few unequivocal conclusions. From this, however, two types of linkage can be identified. The first is the possibility that home ownership has been a contributory cause of the ageing of populations as well as the challenges associated with ageing. This then sets home ownership as an independent variable that may influence demographic developments. The second considers home ownership as a palliator, that is the extent to which it may reduce the severity of some of the problems commonly deemed to result from an ageing Europe, specifically by meeting the income needs of the growing cohorts of older people. The argument is not that this characteristic of home ownership has somehow forced governments to promote home ownership, but rather it has provided them with a reason to do so, and as such may have encouraged some actually to do so.

Whereas a central objective of this paper is to promote the importance of demographic change in understanding housing system change, then, it is an objective based on a recognition that the linkages are not always transparent, not necessarily uniform across countries, and certainly not uncontestable.

\section{AN AGEING EUROPE}

The ageing of the population of the Europeans member states is part of a general, world-wide trend, taking place over the course of perhaps a century and through which there is a shift from high rates of fertility and mortality to low rates of fertility and mortality (Kinsella and Phillips 2005). This demographic transition is bringing to an end an historically short period - much of the middle and latter part of the twentieth century - when European, and indeed other western economies, had, in economic development terms, an unusually favourable age structure. From the 1930s birth rates had been declining thus moving away from the youth dependency of the past, while mortality rates had not yet reduced significantly, retired people were relatively few in number, and age dependency was yet to emerge. In David Coleman's words: "that benevolent phase of population structure, a transitional phase between the youth dependency of the past and the aged dependency of the future, is now going” (Coleman 2001: 2).

There are detailed differences in the extent of these trends between member states. The total fertility rate, or average number of expected births in a woman's life time, has dropped everywhere, but is particularly low in the southern and some eastern member states (Castles 2004; European Commission 2005). Yet, overall the picture is uniform: everywhere the total fertility rate is below replacement levels and everywhere life expectancies have increased with forecasts that they will continue to do so. In 1950, the countries that were to become the EU25, had, on average, only 9.1 per cent of their populations aged 65 and over, with 24.9 per cent under 15, whereas the forecast for a century later shows a reversal to 30.4 per cent and 13.13 per cent respectively (Table 1). Correspondingly, while for every one person of 
retirement age there were 5.52 younger adults aged 25 to 64 years in 1950, the expectation is that by 2050 there will be only 1.52 .

The changes that have occurred already, no less the changes yet set to come, are clearly dramatic and present significant challenges to member states in terms of: reducing economic growth potential below what it might otherwise be; meeting the funding of health care and pension needs because of larger sections of the populations requiring support with smaller sections creating the wealth and paying the taxes to pay for them; and other aspects of welfare (European Communities 2004; Malmberg 2007). As the Kok report concludes "these developments will have profound implications for the European economy and its capability to finance European welfare systems ...the pure impact of ageing populations will be to reduce the potential growth rate.... a GDP per head some $20 \%$ lower than could otherwise be expected .... [and] an increase in pension and healthcare spending by 2050, varying between 4\% and 8\% of GDP” (European Commission 2004:13).

Table 1 Distribution of the population (EU25) by age group

\begin{tabular}{|l|l|l|l|l|l|}
\hline & 1950 & 1975 & 2000 & 2025 & 2050 \\
\hline $80+$ & & & & & \\
\hline $65-79$ & 1.2 & 2.0 & 3.4 & 6.5 & 11.9 \\
\hline $50-64$ & 7.9 & 10.7 & 12.3 & 16.2 & 18.5 \\
\hline $25-49$ & 15.2 & 15.4 & 17.2 & 21.3 & 18.5 \\
\hline $15-24$ & 35.0 & 32.7 & 36.9 & 31.1 & 28.2 \\
\hline $0-14$ & 15.8 & 15.5 & 13.0 & 10.5 & 9.7 \\
\hline & 24.9 & 23.7 & 17.1 & 14.4 & 13.3 \\
\hline $\begin{array}{l}\text { Ratio of older }(>65): \text { younger }(24- \\
\text { 64) adults }\end{array}$ & $1: 5.52$ & $1: 3.79$ & $1: 2.85$ & $1: 2.31$ & $1: 1.52$ \\
\hline Median age & 31 & 33 & 39 & 45 & 48 \\
\hline
\end{tabular}

Source European Commission (2005)

\section{A LIFE CYCLE APPROACH}

A model that facilitates the examination of linkages between trends in demographic structures and the perceived threats they pose is one based on the human life cycle. Advanced economies have varying combinations of institutions, such as civil society organisations, that contribute to the well being of people over the life course, from infancy and childhood when considerable help is needed with respect to basic biological needs as well as the acquisition of social and technical skills necessary for making a living later in the life course, through to old age when increasing frailty may limit the ability independently to sustain a livelihood. The modern welfare state can also be seen as in part fulfilling such functions. The pattern of taxation, particularly based on earned income, achieves a distribution horizontally over the life span which effectively pays for many of the consumption needs of those with little or no earned income: the young who particularly consume education and health care and the old who particularly consume pensions, health and social care. Notwithstanding elements of vertical distribution, in reality a large proportion of the welfare benefits received by individuals are self-financed, making each national welfare system a sort of "savings bank" (Hills 1993: 19). It is precisely because the savings bank is run on a social basis across generations, that the shift in the numerical balance between the generations, requiring a 
shrinking working age population to support an expanding retired population, poses such large challenges.

In addition to, but not independent from, civil society and welfare state institutions, individuals and households appear to organise their financial affairs in a way that mirrors their life course. The life cycle model (LCM) can be thought of as a strategy for the temporal redistribution of income, the basic premise being that, at any one time, individuals set their present level of consumption in relation to their present level of wealth and their expected future income (Deaton 1992). In reality, because for most people the level of income over their life cycle approximates to an inverse U shape, the LCM can be characterised by a number of distinct stages. In the first of these, when individuals are young, their consumption (food, shelter, education and so on) generally exceeds their income so that, in effect, they borrow against future income. In the second stage, when they are in paid employment, their income exceeds their consumption, enabling them to save. In the final stage, that of retirement, consumption needs again generally exceed income so that in order to meet their consumption needs they draw from their savings.

Empirical studies involving many countries show that in practice the period of maximum saving tends to be in late middle age after the child rearing years and before retirement, which points to a general relationship between saving and the age structure of national populations: the aggregate savings rate in a country tends to be "lower when the population share of the elderly is high and when the population share of children is high" (Deaton 2005:13). From this, the impact of ageing populations is unclear: more older people would suggest a high level of dissaving - albeit with life expectancies increasing savings need to last longer so that dissaving may be at a slower rate - while fewer children would increase the saving capacity of adults in the child rearing years.

Notwithstanding this uncertainty, it is clear that housing has the potential to play a particularly important role in the LCM both in general and also in relation to the impact of different population age structures. In most countries housing costs, whether renting or purchasing, constitute a major perhaps the largest single item in household budgets. As such it determines the standard of living of the household both directly through the house itself and indirectly through its impact on the amount of the budget left over to consume non-housing goods. In turn, because housing is expensive relative to incomes it will also impact on the balance between consumption and saving. There is yet a further complication in that housing is itself both an item of consumption and saving. Renters and owners (whether they are outright owners or in the process of purchasing) of dwellings each week consume a flow of housing services; this equates to their housing standard of living. Owners additionally have an investment, which generally in advanced economies has experienced long term growth and which is tradable. People who buy their own homes are therefore both consuming its services over time but also building up their wealth.

Empirical evidence of the role of housing wealth in household decisions about how much to consume in to be found in statistically observable relationships about house price developments and consumer spending. Broadly, across the advanced economies, levels of household consumption increase following periods of rapid house price inflation, indicating that households do appear to treat home ownership as a form of saving (Catte et al 2004). Here it is possible to be more certain about the consequences of ageing, because what has been termed the wealth effect, or the impact of changes in the value of housing assets on the propensity to consume, is greater among older than younger home owners, leading to the 
conclusion that "as the population ages and becomes more concentrated in the old homeowners group, aggregate consumption may become more responsive to house prices" (Campbell and Cocco 2004: 24).

\section{HOME OWNERSHIP AS CAUSE}

One of the main arguments of this paper is that population ageing, both as a trend and as a perceived problem for the fiscal foundations of welfare systems, may be a consequence, at least in part, of home ownership and that the nature of this consequence can be identified in a LCM context. This reverses the logic identified by Castles with housing systems shifting from being the dependent to becoming the independent variable. This can be seen particularly in fertility rates and early retirement.

\section{Fertility Rates}

Much research and indeed policy attention has been directed at the question of why total fertility rates have dropped to their present levels. Attitudinal research carried out over many years appears to indicate that European women would like to have more children than they do (Coleman 2001; European Commission 2004). Some insight into this disparity between behaviour and aspiration is provided not just by developments over time, but also the differences between member states with all having low (below replacement level of about 2.1) rates, while in some, for example the Southern European countries, rates have fallen to what has been termed 'lowest-low fertility'(below 1.3). Methodologically, this crosssectional variation facilitates the search for national, institutional characteristics that underlie the decisions of those of child rearing ages in general. From this factors such as the nature of taxation systems and the degree to which they encourage women to be in paid employment, flexible working time arrangements that allow both men and women to combine working and caring roles, and the availability and costs of child-care facilities - broadly what are termed 'family-friendly' policies - appear to play a significant part (Castles 2004; Dingledy 2001; Sjoberg 2004). Combining both longitudinal and cross-sectional analysis, Castles (2004) has also argued the importance of shifts in values away from assumptions that women's primary role is motherhood and that work and child-rearing are essentially incompatible, towards notions that men and women have equal rights and indeed equal need to undertake paid employment. In his view, it is precisely because the southern countries have labour markets that are less conducive to female employment and cultural values that still consider combining work and motherhood as inappropriate, that in comparison with the greater gender equality of Scandinavian countries, has led to greater reductions in total fertility rates.

Underlying much of these discussions is the financial dimension of childrearing. Notwithstanding the LCM assumption of consumption smoothing, the stark reality facing parents and would-be parents across Europe is that they will have to shoulder a heavy financial burden which may not allow them easily to smooth consumption. Because children cannot support themselves their survival to adulthood is dependent on the ability and willingness of adults to provide them with financial and other resources (Malmberg 2007). In some respects the burden has got larger. For earlier generations, for example, children were expected to contribute to the family income, but the raising of school leaving ages and the expectation of pursuing university level education has now extended the number of years of their dependency (Malmberg 2007). 
Moreover, as Jim Kemeny pointed out some years ago, the burden coincides temporally with the acquisition of home ownership (Kemeny 1981), this arising because the housing stock in most countries is such that the size, layout and location of owner occupied housing is such that, in comparison with rental housing, it offers greater benefits to young families than to singles and couples without children (Mulder and Billari 2006). Couples often move into home ownership in anticipation of or shortly after starting a family. But the financial costs of entry into home ownership are so great that they can lead to a decrease in the probability of having a child. Investigation by Mulder and Billari (2006) suggests that there may be significant cross country differences in this effect, with those countries, such as Spain, Italy and Greece, in which finance markets are not very developed so that access to home ownership is financially difficult, whilst rental opportunities are relatively few, also having the lowest fertility rates.

These arguments are consistent with research that indicates that labour force participation rates for women in the childbearing years tend to be higher in countries whose housing systems provide limited opportunities for acquiring good quality rental housing at reasonable cost pushing younger people toward home ownership (Doling et al 2006). Once the decision has been made to opt for home ownership, however, it often locks both members of a couple "into continuous employment in order to safeguard mortgage repayments" (Hakim 2003: 258). These studies support the contention expressed by the European Commission: "Europeans would like to have more children. But they are discouraged from doing so by all kinds of problems that limit their freedom of choice, including difficulties in finding housing" (European Commission 2005: 2).

The developments in housing systems in western countries, to the point that there are decreasing opportunities to enter rental housing along with house prices that, on the one hand, make entry into home ownership financially difficult and, on the other hand, make home ownership a good avenue for saving, appear to effectively force young households to consume less (other than housing) and save more than they would otherwise do. If this is the case, the assumption of the LCM that households set the level of present consumption with regards to their expectations about their future income and their current wealth, is distorted because home ownership, which effectively has become a necessity for those wishing to rear children, is at the same time both consumption expenditure and saving: for many, its acquisition crowds out non-housing consumption and results in over-saving.

There is here, then, a contradiction. On the one hand, the home ownership stock in many countries seems, in comparison to rental housing, to provide a superior context in which to bring up children; from the point of view of a physical entity the promotion of home ownership could be reasonably described as a family-friendly policy. On the other hand, the front-loaded costs of entry into home ownership that often necessitates the repayment of a loan which constitutes a high proportion of the combined sum of two incomes mitigates against child rearing, so that from a financial perspective the promotion of home ownership can be considered a family-unfriendly policy.

\section{Early retirement}

A corollary of what we have identified as the home ownership based over-saving by younger adults, is that as they age to become older adults home ownership provides opportunities that may exacerbate the impacts of ageing on the viability of welfare arrangements, specifically by facilitating the withdrawal from active participation in the labour market 
before the formal retirement age and thus effectively lowering the dependency ratio and reducing the tax base. The factors underlying individual decisions to stop working at a certain age, are like the factors determining fertility, complex. They include the state of health of the individual and the value they place on leisure time, the nature of pension and wider benefit systems and the incentives they give to carry on or stop work, the nature of the labour market including the opportunities to work part-time (Blondal and Scarpetta 1997; Taylor 2001). Here, also, home ownership appears to be a key factor. The consumption aspect of home ownership means that the outright owner is able to continue to live in the home rent free so that they can, in comparison with renters, get by on a smaller pension (Castles 1998). The investment, particularly if house prices have increased in real terms, also provides owners with at least the possibility of realising some or all of the equity to contribute to an income in old age. The result has been that in western countries with high home ownership rates and high price increases, early retirement is common with some consequent loss of potential economic activity (Doling and Horsewood 2003). In LCM terms, therefore, over-saving, 'forced' by the nature of housing systems, may facilitate dissaving to take place earlier than might otherwise have been the case. If the state promotion of home ownership is, with respect to young adults, a family-unfriendly policy with respect to older adults, it is a work-unfriendly policy.

\section{HOME OWNERSHIP AS PALLIATOR}

Insofar as home ownership may exacerbate the impact of ageing populations by facilitating lower participation rates for older workers, the same features of home ownership also provide a potential palliator. As, over the long run, home ownership sectors have increased in size and house prices have increased in real terms, housing equity has come to constitute the single largest source of wealth held by the average European household. Whereas the precise amounts are unknown, rough estimates indicate that by about 2003 the net value of home owned properties, that is the gross value less outstanding loans, may have been around 15 trillion euros in the EU25 member states (Doling and Ford, 2007). More reliable estimates, but for a smaller group of states, shows that in 2000 in France, Germany and Italy about half of total household wealth was housing wealth, with the proportion being about 65 per cent in Spain, just below 40 per cent in the Netherlands and the UK, and just below 30 per cent in the US (Boone and Girouard 2002). In comparison, the value of the shares held amounted to a quarter or less of total household wealth. The wealth holdings of older Europeans, in their mid 50s and over, are even more skewed toward housing assets (Lefebure et al 2006).

In principle, these are assets that may be used in order to contribute to the income needs of older people; such dissaving could reduce the impact on individual household of the financial effects of withdrawing from paid employment, particularly, where the level of formal pension systems has been reduced. Again, in principle, these are assets that might attract the attention of national governments in seeking to deal with the fiscal consequences of ageing. While the evidence is again patchy and incomplete as well as containing some contradiction, it does provide some support for concluding that the 'in principle' outcomes have become 'in practice' ones.

\section{Dissaving housing assets: household behaviour}

The first aspect of this concerns the extent to which European households see their homes in these terms: is home ownership universally seen as a financial asset? And, if they do, how in practice do they use that asset? 
The evidence here is particularly contradictory. On the one hand, recent research indicates that, over the last almost 30 years in each of 10 OECD countries, whenever there has been a large annual increase in house prices, and therefore in the value of housing equity, this has had a downward effect on the amount of money that households saved in that year.(Doling and Horsewood 2008b). It might be concluded from this that households really do see housing as saving and that they organise their affairs accordingly, reducing their additional savings in response to increases in the value of their housing equity. Moreover, the effect appears to operate across a range of European countries including southern countries. So, perhaps uniformly across Europe, households see home ownership as saving.

On the other hand, the extent to which the use of housing assets varies with the age of the head of household has been examined in a number of econometric studies based on a LCM framework and suggests a reluctance to utilise that saving in old age. Many of these studies have used data for the US or the UK for the 1980s and 1990s, their results indicating that moving out of home ownership into rental housing, downsizing or otherwise drawing on equity in order to support consumption as families age was not widespread in those decades, an exception often occurring with the death of one partner or a move into a nursing home (Venti and Wise 2001; Rohe et al 2002; Feinstein and McFadden 1989; Ermisch and Jenkins 1999; Disney et al 1998 ). More recent analysis with a European focus, broadly confirmed these findings while also indicating important differences between countries. Most European households who are home owners by their late fifties remain so throughout their remaining working and their retirement years, so that there is not evidence of large scale decumulation of housing assets. Nevertheless, there is evidence of some decumulation as people get older as well as significant regional differences. Particularly where housing costs are high and following the death of a spouse, the mobility rates of older Europeans increase, marking a general, but not large-scale, tendency to move into rental housing or to remain in home ownership but move to a smaller dwelling (Tatsiramos 2006). Older people in the Southern member states (Italy, Greece, Portugal and Spain) are less likely than their counterparts in the other western member states to move at all, or to move into smaller dwelling or out of home ownership.

The general picture then is that older people have limited propensity to use their homes as a source of wealth that might contribute to their income needs There may be two sets of reasons for this reluctance, one based in the nature of home ownership and of national housing systems, and one in the nature of different sources of wealth and household motives. Both are reviewed her, leading into a discussion of whether household motives are changing.

\section{The nature of home ownership}

The apparent reluctance of older owners to move out of their home (to move down market or out of market) may be a function of one or more housing and housing market attributes. The fact that home ownership is both a consumption and an investment good complicates the dissaving decision, because any form of dissaving that involves moving from the house, necessarily changes the households' pattern of consumption But it is a consumption that may have considerable psychic or emotional attachment. Established family and friendship networks, reliance on neighbourhood institutions along with a store of personal memories attached to the house itself can make changing one's home of a different dimension to changing the refrigerator or the car. In some countries the transaction costs, including legal fees and taxation, involved in selling a house, and in purchasing another, are particularly high making the realisation of this form of wealth more expensive than other forms. For 
example, transaction costs are relatively low in the UK and Scandinavia, and relatively high in Southern Europe (OECD 2004) In some countries access to decent and reasonably-priced rental accommodation may be restricted because of a shortage of supply or of rules of access. (Rouwendal 2008). Particularly in southern European countries housing is central to the larger, extended family project, not to be bought and sold but acquired on behalf of the whole family and passed through the generations. (Earley 2004, Allen et al 2004).

The extent of such dampening effects on dissaving is significant because generally most equity withdrawal appears to occur when people move (Committee on the Global Financial System 2006). This suggests the potential of using financial products, such as reverse mortgages, since they enable dissaving without moving. Whereas European financial institutions are expanding the number and range of financial products available to households, (European Mortgage Federation 2006), they are not uniformly available across Europe (ECB 2003). At the present time, therefore this is not an option for all Europeans and, even where it is, it is not widely pursued.

\section{The nature of savings}

The apparent reluctance to pursue strategies that release housing equity can be contributed to the nature of different sources of savings or wealth. Wealth held by older people can be usefully divided in two categories. Annuity wealth provides an income stream, the level of which could be constant, in nominal or real terms, or subject to change imposed by an external agent, such as the government, and which would terminate on the death of the recipient. Generally, annuity wealth includes pensions and other social benefits.

Bequeathable wealth, which includes housing assets, as well as other forms of savings such as cash, shares and durable goods, can be consumed at a rate determined by the individual and passed to an heir at death.

The bequest motive provides an addition to the LCM since it implies that individuals may not seek to reduce their wealth holding in old age but rather to hold on to their wealth or even to increase it. Somewhat confusingly, empirical examination of the rate of dissaving of older people - at least in the US - indicate that starting from the same level of resources, older people, whether single or couples, with children do not dissave more than their counterparts without children. (Hurd 1990, Chiuri and Jappelli 2006).

In addition to the bequest motive, it is also possible that households pursue a precautionary savings motive, saving now against future financial shocks. This also provides an addition to the LCM: "Uncertainty about the life-span, about health and health costs, and the extreme unpleasantness of poverty in old age, combine to make older people extremely cautious about running down their assets. Such behaviour also explains, at least partially, the important role of accidental bequests in the transmission of wealth,” (Deatonn 1992: 192).

The bequest and precautionary motives, then, both offer possible understanding of why older people may be reluctant to dissave in the way suggested by the LCM. But, insofar as they are willing to dissave, might there be further reasons why they are more reluctant to use housing wealth than other wealth? One possibility lies in attitudes to risk. In comparison with younger people, older people tend to be less risk tolerant. In general, they are less willing to accept any risk with their investments, let alone higher than average risks, in return for the possibility of earning average, or higher, returns (Poterba 1998). Given this, it can be anticipated that as people age they will tend to dispose of risky or volatile assets such as 
shares before less risky ones such as their homes, and both before the least volatile such as cash and government bonds.

For two further reasons, it can be expected, that couples will dissave less than people living on their own. Firstly, because the living costs of two people sharing are less than twice the living costs of a single person, so that for a given standard of living there is less need to cash in savings. Secondly, the probability that both members of a couple will die in the following year is less than the probability that a single person will die and so the expected time over which savings will need to be eked out is longer for the couple. Overall, the outcome could be "a flat or slowly falling wealth path of the couple until one spouse dies. Then the survivor would switch to the more steeply falling path of a single” (Hurd 1990: 613).

\section{Changing attitudes}

A common factor underlying the studies mapping the dissaving behaviour of older people is that they are based on historical data, much of it from the 1980s and 1990s. By definition, these data do not enable the identification of contemporary trends, one of which is the increasing tendency for households, at least in some countries, to view their home as a store of wealth which may be used to facilitate future consumption (Smith 2005; Stone 2003). Indeed much of this is couched in terms of housing as a safety net, as a source of pension and as a vehicle for realising money when the owners want it. Moreover, there is evidence that insofar as this intended to fund future consumption, it is consumption for themselves rather than for future generations. In recent years the practice of SKIING (Spending the Kids' Inheritance) has gained some popular recognition, arguably reflecting a new reality in which the bequest motive has become less dominant. Moreover, it is possible that, as more people reach old age without having had children, questions of the home as a bequest and the significance of intergenerational transfers and solidarity take on a different hue: some might want to leave a bequest to do good things for fellow man, or even the stray dogs of the neighbourhood, but evidence from the UK indicates that increasing numbers of people want to spend it on themselves (Rowlingson and McKay 2007). In that way SKIING simply becomes SING (Spending). Australian evidence on this is particularly interesting in that it indicates a clear distinction between the 50-65 and the 65 plus cohort in that the latter hold on to the notion of the house as a bequest for their children while the former are very much more determined to ensure a continuation of the quality of life achieved during their working yeas, if necessary by using their housing equity ((SEQUAL 2008).

\section{Dissaving housing assets: government behaviour}

The question of whether households see home ownership as a form of saving and how they use that saving can also be extend to governments. While concern about the negative impact of ageing is clearly and frequently expressed by politicians and civil servants at the level of the European Union (eg European Communities 2004; European Commission 2005), competence over the relevant policy fields is vested with the individual member states and, as usual in such circumstances, there is not an expression or a reality of a unified effort to use home ownership as a palliator. Perhaps the nearest to this was a communiqué issued at the end of a meeting in 1999 of the housing ministers of all the then EU member states. Their position was that older home owners should make use of their housing assets to pay for their old age:

In most EU Member States, older people live in owner-occupied housing. This means that many older people possess capital in the ownership of their homes. The Ministers 
were aware of the need to explore new ways of helping older people to safely utilize their capital, for example, to obtain the housing and support services they need, to repair or adapt their existing homes or to release income to cover the costs of support services or to purchase new accommodation with support services available (Finland 1999; para 9)

Beyond this, statements have been ad hoc and country specific. Thus the socialist party in Flanders has quite explicitly argued that further growth of home ownership should be encouraged because it provides the best way to live and to save for a pension (Sp.a 2007). Some statements (ODPM 2005) are consistent with a more general developments in the systems of social protection in some member states through the promotion of asset-based welfare (Doling and Ronald forthcoming). The point here is that home ownership can be seen as a means whereby individuals may build up a sort of personal provident fund which can be called upon when needed. In that way, forced, personal saving in the housing market may be viewed as substituting for tax and public spending.

Whatever the impact of explicit goals and de jure action to increase home ownership, it does appear that over the quarter of a century up to 2003 there has been a de facto substitution of housing assets for state expenditure on older people (Doling and Horsewood 2008a). In the OECD countries, unusually large annual increases in house prices, and thus in housing assets, have been followed by reductions in state spending on pensions and other welfare benefits for older people. The corollary is that unusually small increases, or even decreases, in house prices are followed by increases in the generosity of state spending. In other words, housing appears to act as an independent variable causing, or leading to, a change in the level of state provision. While it is not clear what processes lead to the trade-off, the size of the effect is greatest in those countries in which, on the one hand, their governments provide the most generous benefits and so there is numerically the greatest pressure on them to find ways of reducing the fiscal challenges of older people, and, on the other hand, where pension and other benefit entitlements and housing wealth are distributed similarly. The reality then is that even without being an overt policy, across the larger economies, both within and without Europe, housing wealth appears to have relieved some of the fiscal pressures arsing form population ageing.

\section{CONCLUDING COMMENTS}

The argument in this paper has not been that European governments have responded directly and overtly to the ageing of their populations by cutting social housing programmes and expanding home ownership. In that sense, it does not support what Castles presented as the logic of the argument put forward by proponents of the view that ageing populations inevitably bring about welfare system development. Rather, the argument has been that the increases over recent decades in home ownership sectors across the EU are consistent with the attraction of home ownership as palliator, in that it may be seen as having the potential to ameliorate some of the negative consequences of ageing populations.

The evidence presented in support of this argument is certainly not conclusive. This is partly because it is not drawn systematically from all European countries, let alone all western European countries; even so, there appear to be differences in their experiences. It is also partly a consequence of contradictions between different studies. Nevertheless, there appears to be some substance to the position that in some Euroepan countries increasing reliance is being put on the equity held in the form of home ownership, that this is in some ways substituting for 
pensions and other expenditures on older people and that, in at least some respects, this is being driven by demographic trends.

One pillar of the argument is that overall European households appear increasingly to be viewing home ownership as a source of wealth as well as a place to live. Moreover, as a source of wealth it is one which they may draw upon to support their consumption in old age. It is possible that the SKIING motive is eclipsing the bequest motive, perhaps not least because one of the features of demographic ageing is that fewer older Europeans will have children anyway. It is also possible that changing attitudes to the uses of housing are themselves driven, in part, by the concerns of households about the wisdom of relying on government support in a future of intense fiscal pressure.

The second pillar of the argument concerns governments. There is evidence relating to all those that were member states in 1999 of overt consensus around the use of home ownership to support older people's needs as well as relating to overt promotion of home ownership by some, individual member states. Whereas this interest by European governments seems consistent with an equity-based welfare philosophy it is not widespread. In addition to overt policy, there is evidence that increases in housing wealth over a number of decades has been followed by decreasing state expenditure on older people, and whatever the processes it points to a reality of home ownership substituting for pensions.

Such a conclusion points to the possibility that in response to population ageing European households and governments have been acting in a way that has promoted the expansion of home ownership. Insofar as that is the case then clearly explanations about the growth of home ownership and the decline of other sectors that have emphasised globalisation may need to be adapted to incorporate population ageing.

In addition to implications for theory, there are also implications for policy. The first concerns the consequences of substituting individual responsibility for pension provision through home ownership for state responsibility through pensions. In that this weakens the social insurance principles of pension systems the result may well to be an increase in both inequality and the risk of poverty among older people. Such concern merits detailed and systematic examination of the distributional consequences of policy change.

A second implication is that throughout Europe the baby boomer generation, those born in the decade or so immediately following the end of the Second World War, have perhaps contributed greatly to the growth of asset prices, including house prices, from the mid 1990s onwards. Whether or not that has been the case, an issue of major significance concerns the possible consequence of the decumulation activities of the baby boomers as they move into the retirement ages. For the US, Schieber and Stevens (1997) have developed the argument that as pension systems move into a situation of being net sellers of assets, the result could be to depress asset prices, whether these be stocks, bonds, land or real estate. Insofar as life cycle savings constitute household pension systems, the same argument would apply to any mass selling of individually owned homes with a view either to moving to a cheaper house, or to transfer into rental housing.

It is important to emphasise another general position pursued in this paper. The relationship between housing and demographic change is even more complex than indicated by the concluding comments here. As the paper has shown, there is evidence that home ownership has directly contributed to the degree of demographic change through the impact that access 
to home ownership, in its financial implications, has on the ability of young people to get housing that is well-suited to bringing up a family and meeting the other financial needs of child rearing. If in some respects the state promotion of home ownership can be viewed as a family-unfriendly policy, so its facilitating of early retirement might lead to the conclusion that it is a work-unfriendly policy also. Moreover, in a way these two are linked. Insofar as young people are forced to 'over-save' the pay-off is that they may be able to get by on lower incomes earlier than formal state retirement ages anticipate. It is here that home ownership as a cause and as a palliator are linked.

\section{REFERENCES}

Allen J, Barlow J, Leal J, Maloutas T and Padovani L (2004) Housing and Welfare in Southern Europe, Blackwell: Oxford

Arthur S (2003) The Financial Circumstances of Early Retirement, Joseph Rowntree Foundation: York

Bardasi E, Jenkins S P, Rigg J A (2002) Retirement and The Income of Older People: A British Perspective, Ageing and Society, 22: 131-159.

Blondal S and Scarpetta S (1997) Early Retirement in OECD Countries: The Role of Social Security Systems, OECD Economic Studies, 29: 7.49.

Boone L and Girouard N (2002) The Stock Market, the Housing Market and Consumer Behaviour, OECD Economic Studies, 35 (2) 275-200.

Campbell J and Cocco J (2004) How Do House Prices Affect Consumption? Evidence from Micro Data, Discussion Paper 2045, Harvard Institute of Economic Research.

Catte P, Girouard N, Price R and Andre C (2004) Housing Markets, Wealth and the Business Cycle, Economics Department Working Paper No 194, OECD: Paris

Churi M and Jappelli T (2006) Do the Elderly Reduce Housing Equity? An International Comparison, Working Paper no 158, Centre for Studies in Economics and Finance, University of Salerno.

Coleman D (2001) Population Ageing: An Unavoidable Future, Social Biology and Human Affairs, 66: 1-11.

Committee on the Global Financial System (2006) Housing Finance in the Global Financial Market, CGFS Papers No 26, Bank of International Settlements,

Deaton A (1992) Understanding Consumption, Clarendon Press, Oxford. 
Deaton A (2005) Franco Modigliani and the Life Cycle Theory of Consumption

Dingledley I (2001) European Tax Systems and their Impact on Family Employment Patterns, Journal of Social Policy, 30 (4) 653-672.

Disney R, Johnson P and Stears G (1998) Asset Wealth and Asset Decumulation among Households in the Retirement Survey, Fiscal Studies, 19 (2) 153-174.

Doling J and Ford J (2003) Globalisation and Home Ownership: Experiences in Eight Member States of the European Union, Delft University Press.

Doling J and Ford J (2007) A Union of Home Owners, Editorial, European Journal of Housing Policy, 7 (2) 113-117.

Doling J and Horsewood N (2003) Home Ownership and Early Retirement: European Experience in the 1990s, Journal of Housing and the Built Environment, 18: 289-308.

Doling J and Horsewood N (2008a) Home Ownership and Pensions: Testing the Trade Off, DEMHOW Report to European Commission.

Doling J and Horsewood N (2008b) Understanding Savings in EU Countries: The Role of Housing, Stock Markets and Demographics, Paper to ENHR Working Group Conference, Istanbul.

Doling J, Horsewood N, Kassanis A, Vasilakos N (2006) Home Ownership and Labour Force Participation of Younger People, in Horsewood N and Neuteboom P (ed) The Social Limits to Growth: Security and Insecurity Aspects of Home Ownership, IOS Press:

Amsterdam.

Doling J and Ronald R (eds) (forthcoming) Special issue on property-asset-based welfare, Journal of Housing and the built Environment.

Earley F (2004) What Explains the Differences in Home Ownership Rates in Europe? Housing Finance International, September

Ermisch J and Jenkins S (1999) Retirement and Housing Adjustment in Later Life: Evidence from the British Household Panel Survey, Labour Economics, 6: 311-333.

ECB (2003) Structural Factors in the EU Housing Markets, European Central Bank: Frankfurt.

European Commission (2005) Green Paper. Confronting Demographic Change: A New Solidarity between the Generations, COM (2005) 94 final, Commission of the European Communities, Brussels

European Communities (2004) Facing the Challenge: The Lisbon Strategy for Growth and Employment, Report of the High level Group chaired by Wim Kok, Office for Official Publications of the European Communities: Luxembourg 
European Mortgage Federation (2006) Hypostat 2005, European Mortgage Federation, Brussels.

Feinstein J and McFadden D (1989) The Dynamics of Housing Demand by the Elderly: Wealth, Cash Flow and Demographic Effects, in Wise D A (ed) Economics of Aging, University of Chicago Press: Chicago.

Hakim C (2003) Models of the Family in Modern Societies: Ideals and Realities, Ashgate: Aldershot.

Hancock R (2000) Estimating the Housing Wealth of Older Home Owners in Britain, Housing Studies, 15 (4) 561-579.

Hills J (1993) The Future of Welfare: A Guide to the Debate, Joseph Rowntree Foundation: York

Hurd M (1990) Research on the Elderly: Economic Status, Retirement, and Consumption and Saving, Journal of Economic Literature, vol XXVIII, 565-637.

Kinsella K and Phillips D (2005) Global Aging: The Challenge of Success, 60 (1), Population Reference Bureau: Washington DC

Lefebure S, Mangeleer J and Van den Bosch K (2006) Elderly Prosperity and Homeownership in the European Union: New Evidence from the SHARE Data, Paper to the $29^{\text {th }}$ General Conference of the International Association for Research in Income and Wealth, Joensuu, Finland.

Malmberg B (2007) Demography and Social Welfare, Journal of International Social Welfare, 16: S21-S34

Malpass P (2006) Housing Policy in an Opportunity Society: Home Ownership and the Amplification of Inequality, in Doling J and Elsinga M (eds) Home Ownership: Getting In, Getting From, Getting Out Part II, IOS Press, Amsterdam

Mulder C and Billari F (2006) Home-ownership Regimes and Lowest-low Fertility, Paper to ENHR working group conference, Delft.

ODPM (2005) Homes for All - Expanding Opportunities for Home-ownership, Press release 36/05, 1 April, Office of the Deputy prime Minister.

OECD (2004) Housing Markets, Wealth and the Life Cycle, OECD Economic Outlook, June.

Poterba J (1998) Population Age Structure and Asset Returns: An Empirical Investigation, Working Paper 6774, National Bureau of Economic Research, Cambridge, Mass. 
Rohe W M, Von Shandt S and McCarthy G (2002) Home Ownership and Access to Opportunity, Housing Studies, 17 (1) 51-61.

Ronald R (2008) The Ideology of Home Ownership: Homeowner Societies and the Role of Housing, Palgrave Macmillan: Basingstoke.

Rowlingson K and McKay S (2007) Attitudes to inheritance in Britain, Rowntree Foundation, York

Schieber S and Shoven J (1997) The Consequences of Population Aging on Private Pension Fund Saving and Asset Markets, in Schieber and Shoven (eds) Public Policy Towards Pensions, MIT Press, Camb, 219-245.

SEQUAL (2008) “It's on the House” A Consumer Study into the Attitude and Perceptions of Australians aged over 60 years. Senior Australian Equity Release Association of Lenders, Sydney

Sjoberg O (2004) The Role of Family Policy Institution in Explaining Gender-Role Attitudes: A Comparative Multilevel Analysis of Thirteen industrialized Countries, Journal of European Social Policy, 14 (2) 107-123.

Smith, S. (2005) Banking on housing? Speculating on the role and relevance of housing wealth in Britain, paper prepared for the Joseph Rowntree Foundation Inquiry into Homeownership 2010 and beyond

Stephens M (2003) Globalisation and Housing Finance Systems in Advanced and Transitional Economies, Urban Studies, 40 (5-6) 1011-1026.

Stone M (2003) Safe as Houses, Prudential: London.

Tatsiramos K (2006) Residential Mobility and Housing Adjustment of Older Households in Europe, Discussion Paper No. 2435, Forscchunginstitut zur Zukunft der Arbeit (IZA), Bonn

Taylor P (2001) Reversing the Early Retirement Trend, Labour Market Trends, April: 217220.

Venti S F and Wise D A (2001) Aging and Housing Equity: Another Look, NBER Working Paper w8608

Whiteford P and Kennedy S (1995) Income and Living Standards of Older People: A Comparative Analysis, Department of Social Security Research, HMSO: London 
